\title{
Growth, Physiological Studies and Yield of Taro (Colocasia esculenta Schott) cv. Mukhi Pan as Influenced by Intercropping and Row Pattern under Manipur Condition
}

\author{
Momoko Thokchom ${ }^{1 *}$, Loitongbam Sulochana Devi ${ }^{1}$, Ravi Kiran Thirumdasu ${ }^{2}$, \\ A.K. Bijaya Devi ${ }^{1}$ and K.H. James ${ }^{1}$
}

\author{
${ }^{1}$ Department of Horticulture, college of agriculture, Central Agricultural University, \\ Imphal-795004, Manipur, India \\ ${ }^{2}$ Department of Vegetable and Spice Crops, Faculty of Horticulture, Uttar Banga Krishi \\ Viswavidyalaya, Pundibari, Cooch Behar 736165 West Bengal, India
}

*Corresponding author

\section{A B S T R A C T}

\begin{tabular}{|l|}
\hline Ke y w o r d s \\
Colocasia, \\
Intercropping, \\
Spices, \\
Physiological \\
\hline Article Info \\
\hline $\begin{array}{l}\text { Accepted: } \\
\text { 10 April } 2018 \\
\text { Available Online: } \\
10 \text { May } 2018\end{array}$ \\
\hline
\end{tabular}

\begin{abstract}
An investigation was carried out to study the effect of intercropping on growth, physiological aspects and yield of taro with constant spacing of $60 \times 45 \mathrm{~cm}$ (sole crop), $30 \times 15 \mathrm{~cm}$ between (cowpea and French bean) and $35 \times 20 \mathrm{~cm}$ (ginger and turmeric) in single and double row planting system. The growth parameters of taro were recorded significantly highest under sole cropping of colocasia whereas petiole diameter was found to be significant in taro with single row ginger. Whole plant fresh weight $(531.81 \mathrm{~g})$ and dry weight (106.29 g) were recorded significantly highest under sole cropping. Physiological parameters like leaf area index (2.47) and harvest index $(83.15 \%)$ were found highest in taro sole crop at 120 days after planting. At 60-90 DAP, highest net assimilation rate was observed in taro with single row of turmeric $\left(0.003 \mathrm{~g} \mathrm{~m}^{-2}\right.$ day $\left.^{-1}\right)$. However maximum corm yield of taro (23.90 t/ha) was recorded from sole crop. Among the intercropped treatments maximum taro yield $(19.20 \mathrm{t} / \mathrm{ha})$ was recorded in combination with single row of cowpea.
\end{abstract}

\section{Introduction}

Taro (Colocasia esculenta Schott; family Araceae) commonly called as eddoe or arvi, an important perennial tuber crop grown for the edible supplementing carbohydrate in the diet of India, tropics, Pacific islands, Africa and other South East Asian countries. Taro is an excellent multipurpose crop for subsistence agriculture giving food security. Cooked tender leaves have the same nutritional value of spinach, also contains vitamin B-complex than whole milk and dietary protein. This might have been a reason that taro became part of Manipuri ethnic cuisines like Utti etc. Given the importance, it is necessary to enhance the production of taro in this region. Really it's a great challenge to enhance the taro production in a limited piece of land. As taro is a long duration crop, production could be augmented through efficient utilization of available sunlight, water and nutrients 
between rows by intercrops like French bean, cowpea, ginger and turmeric. This system of intercropping can be practiced based on the extent of spatial arrangement of the crop (Oguzor, 2007). However different intercrops and level of intercropping combinations play important role in competition for available resources and effect the growth (Oliveira et al., 2004; 2007) and yield (Sagos et al., 2004; Zarate et al., 2006; 2007; Mabhaudhi et al., 2013) of taro in an intercropping system. Hence physiological growth analysis (Hokmalipour and Darbandi, 2011) of component crop can be a meaningful measure for degree of competition and performance. Keeping in view of above aspects, the present investigation has been taken up to study the growth, physiological aspects and yield of taro when planted with and without intercrops.

\section{Materials and Methods}

The present investigation was carried out at Horticultural research farm, Department of Horticulture, college of agriculture, Central Agricultural University, Imphal, during 20132014.

The experimental soil is of Acidic ( $\mathrm{pH} 4.48$ ) and clay soil. The experiment was laid out in a randomized block design with thirteen treatments and three replications. The soil of the experimental site was clay in texture with acidic in reaction ( $\mathrm{pH} 4.8)$, medium in organic carbon content, medium in available nitrogen and phosphorus and high in potassium. The amount of fertilizer for taro (80:60:60 Kg/ha) to sole and intercrop, cowpea sole crop (20:12:8 kg/ha), French bean sole crop (30:16:48 kg/ha), turmeric sole crop (30:12:48 $\mathrm{kg} / \mathrm{ha}$ ) and ginger sole crop (75:20:40 kg/ha) was applied as basal dose and at the time of earthing up (30 days after planting). The treatments comprised of $\mathrm{T}_{1}$-taro sole crop, $\mathrm{T}_{2}$ taro + cowpea (1:1), $\mathrm{T}_{3}$ - taro + cowpea (1:2), $\mathrm{T}_{4}$ - taro + French bean $(1: 1), \mathrm{T}_{5^{-}}$taro + French bean (1:2), $\mathrm{T}_{6}$ - taro + turmeric $(1: 1), \mathrm{T}_{7-}$ taro + turmeric (1:2), $\mathrm{T}_{8^{-}}$taro + ginger (1:1), $\mathrm{T}_{9^{-}}$taro + ginger (1:2), $\mathrm{T}_{10}$ - cowpea as sole crop, $\mathrm{T}_{11^{-}}$ French bean as sole crop, $\mathrm{T}_{12}$ - turmeric as sole crop and $\mathrm{T}_{13^{-}}$ginger as sole crop. Varieties planted are taro (cv. Mukhi Pan), cowpea (yard long bean), French bean (Pant Anupama), turmeric (Local collection from Bishnupur) and ginger (Local collection from Bishnupur). Constant spacing of $60 \times 45 \mathrm{~cm}$ followed in taro, $30 \times 15 \mathrm{~cm}$ for cowpea, French bean and $35 \times 20 \mathrm{~cm}$ for ginger and turmeric. Whereas single and double row planting consists intercrops of one and two rows in inter-rows of taro. Five uniform plants were selected randomly in each treatment for recording plant height $(\mathrm{cm})$, plant canopy $\left(\mathrm{cm}^{2}\right)$, petiole diameter $(\mathrm{cm})$, number of leaves and leaf area $\left(\mathrm{cm}^{2}\right)$ at 180 days after planting.

The following method (Biradar et al., 1978) has been used to measure the leaf area (Y) of taro.

$\mathrm{Y}=0.917 \times \mathrm{P}$

Where, $\mathrm{P}=$ Product of length $\mathrm{x}$ breath of the leaf

Whole plant fresh weight, whole plant dry weight, fresh weight and dry weight of the corm and cormels were measured at 60, 90 and 120 days after planting, Leaf area index (LAI) (Watson, 1947), harvest index (Yoshida, 1981) and net assimilation rate (NAR) (Gregory, 1926) were calculated by given formula.

LAI $=$ Total Leaf Area $\left(\mathrm{cm}^{2}\right) /$ Canopy of the plant $\left(\mathrm{cm}^{2}\right)$

Harvest index $=($ Economic yield $/$ Biological yield) x 100

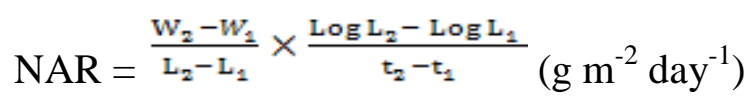


Where, $\mathrm{W}_{1}, \mathrm{~W}_{2}$ and $\mathrm{L}_{1}, \mathrm{~L}_{2}$ refer to the whole plant dry weight and Leaf area on two successive periods at $t_{1}$ and $t_{2}$. Rhizome weight $(\mathrm{g})$ of the intercrops has been recorded on per plant basis.

\section{Results and Discussion}

Intercropping was shown significant effect on taro growth, physiological aspects and yield. The result revealed that growth parameters (Table 1) of taro viz., plant height $(118.33 \mathrm{~cm})$, plant canopy $\left(5800.20 \mathrm{~cm}^{2}\right)$, number of leaves (6.89) and leave area $\left(2931.18 \mathrm{~cm}^{2}\right)$ were recorded significantly highest under sole cropping of colocasia $\left(\mathrm{T}_{1}\right)$ at 150 DAP whereas petiole diameter (8.49) was found to be significant in taro with single row ginger. Total fresh weight of corm and cormels (442.14 g) and total dry weight of corm and cormels (99.59 g), number of cormels (11.78), whole plant fresh weight $(531.81 \mathrm{~cm})$ and whole plant dry weight (106.29 g) were recorded significantly highest under sole cropping of colocasia $\left(\mathrm{T}_{1}\right)$. Whereas statistically at par results was recorded from taro + single row French bean $\left(\mathrm{T}_{4}\right)(108.22$ $\mathrm{cm})$ and taro + single row cowpea $\left(\mathrm{T}_{2}\right)$ $(105.78 \mathrm{~cm})$ for plant height, taro + single row ginger $\left(\mathrm{T}_{8}\right)\left(5222.41 \mathrm{~cm}^{2}\right)$ and taro + single row French bean $\left(\mathrm{T}_{4}\right)\left(5082.46 \mathrm{~cm}^{2}\right)$ for plant canopy, taro + double row French bean $\left(\mathrm{T}_{5}\right)$ $(7.28 \mathrm{~cm})$ and taro + single row ginger $\left(\mathrm{T}_{8}\right)$ $(7.20 \mathrm{~cm})$ for petiole diameter, taro + single row ginger $\left(\mathrm{T}_{8}\right)(5.11)$ and taro + single row French bean $\left(\mathrm{T}_{4}\right)$ (4.78) for number of leaves per plant, taro + single row cowpea $\left(\mathrm{T}_{2}\right)$ $\left(2002.12 \mathrm{~cm}^{2}\right)$ for leaf area.

In line with the above findings superior performance of sole crop in terms of plant height, plant canopy, petiole diameter, number of leaves per plant and leaf area was also revealed in the experiments of Oliveira et al., (2007), Chattopadhyay et al., (2008), Osundare and Agboola (2003) and Thirumdasu et al., (2015), respectively. Fresh and dry weigh of plants are important traits, as they are directly related to the dry matter and food reserve accumulation in plants. Corm and cormels development started well ahead 90 days after planting demanding more diversion of assimilates for the development of corm and cormels. Thus photosynthates produced were mostly used for the development of corm and cormels in the expense of the growth of the plant and thereby the plant height was found to be decreased after 150 days after planting. Large sized corms in sole crop might be due to the translocation of greater quantity of dry matter into the corm from the plant canopy in the absence of interspecific competition for resources. The results are in conformity with the finding of Zarate et al., (2007) and Thirumdasu et al., (2015) (Table 2).

\section{Physiological parameters}

The present study showed significant differences among the different treatments with respect to physiological parameters. Leaf area index (2.47) and harvest index $(83.15 \%)$ were found highest in taro sole crop at 120 days after planting. The leaf area index increased with the advancing of days which was due to the production of more number of leaves at early stages. Similar findings were also confirmed by Njoku and Muoneke (2008) in cassava- cowpea intercropping system and Daellenbach et al., (2005), respectively. In the experiment, there were significant differences among the treatments and showed decreasing rate of net assimilation with advancing duration of the crop. At 60-90 DAP, the highest net assimilation rate was observed in taro with single row of turmeric $\left(0.003 \mathrm{~g} \mathrm{~m}^{-2}\right.$ day $\left.^{-1}\right)$ which was at par with all the treatments except taro sole crop $\left(0.002 \mathrm{~g} \mathrm{~m}^{-2} \mathrm{day}^{-1}\right)$. The minimum was observed in taro with double row turmeric $\left(0.00013 \mathrm{~g} \mathrm{~m}^{-2} \mathrm{day}^{-1}\right)$. This result was in conformity with the findings of Kuhlase et al., (2009) (Table 3). 
Int.J.Curr.Microbiol.App.Sci (2018) 7(5): 925-931

Table.1 Growth parameters of taro cv. Mukhi Pan at 150 days after planting

\begin{tabular}{|c|c|c|c|c|c|}
\hline Treatments & $\begin{array}{c}\text { Plant } \\
\text { height } \\
(\mathbf{c m})\end{array}$ & $\begin{array}{c}\text { Plant canopy } \\
\left(\mathbf{c m}^{2}\right)\end{array}$ & $\begin{array}{c}\text { Petiole } \\
\text { diameter } \\
(\mathbf{c m})\end{array}$ & $\begin{array}{c}\text { Number } \\
\text { of leaves }\end{array}$ & $\begin{array}{c}\text { Leaf area } \\
\left(\mathbf{c m}^{2}\right)\end{array}$ \\
\hline $\mathrm{T}_{1}$ & 118.33 & 5800.20 & 8.34 & 6.89 & 2931.18 \\
\hline $\mathrm{T}_{2}$ & 114.11 & 5726.18 & 8.09 & 5.89 & 2492.45 \\
\hline $\mathrm{T}_{3}$ & 114.89 & 4993.12 & 7.56 & 6.00 & 2624.12 \\
\hline $\mathrm{T}_{4}$ & 116.33 & 5082.06 & 7.97 & 6.56 & 2560.82 \\
\hline $\mathrm{T}_{5}$ & 109.55 & 4861.22 & 8.28 & 5.89 & 2636.80 \\
\hline $\mathrm{T}_{6}$ & 94.67 & 5182.04 & 7.15 & 6.33 & 2812.06 \\
\hline $\mathrm{T}_{7}$ & 111.11 & 4731.68 & 8.20 & 6.00 & 2230.94 \\
\hline $\mathrm{T}_{8}$ & 110.44 & 5532.80 & 8.49 & 6.67 & 2425.34 \\
\hline $\mathrm{T}_{9}$ & 114.33 & 4963.34 & 7.51 & 6.32 & 2564.20 \\
\hline S.Ed( $\mathbf{E})$ & 4.76 & 158.15 & 0.32 & 0.17 & 97.88 \\
\hline CD $(\mathbf{0 . 0 5})$ & 10.09 & 335.27 & 0.68 & 0.36 & 207.51 \\
\hline
\end{tabular}

Table.2 Effect of intercropping spice crops on destructive samples of taro cv. Mukhi Pan

\begin{tabular}{|c|c|c|c|c|c|c|c|c|c|c|c|c|}
\hline \multirow[t]{2}{*}{ Treatments } & \multicolumn{3}{|c|}{$\begin{array}{l}\text { Whole plant fresh } \\
\text { weight (g) }\end{array}$} & \multicolumn{3}{|c|}{$\begin{array}{l}\text { Whole plant dry weight } \\
\text { (g) }\end{array}$} & \multicolumn{3}{|c|}{$\begin{array}{l}\text { Fresh weight of corm } \\
\text { and cormels ( } \mathrm{g} \text { ) }\end{array}$} & \multicolumn{3}{|c|}{$\begin{array}{l}\text { Dry weight of corm } \\
\text { and cormels (g) }\end{array}$} \\
\hline & $\begin{array}{c}\text { 60 } \\
\text { DAP }\end{array}$ & $\begin{array}{c}90 \\
\text { DAP }\end{array}$ & $\begin{array}{l}120 \\
\text { DAP }\end{array}$ & $\begin{array}{c}\text { 60 } \\
\text { DAP }\end{array}$ & $\begin{array}{c}90 \\
\text { DAP }\end{array}$ & $\begin{array}{c}120 \\
\text { DAP }\end{array}$ & $\begin{array}{c}\text { 60 } \\
\text { DAP }\end{array}$ & $\begin{array}{c}90 \\
\text { DAP }\end{array}$ & $\begin{array}{c}120 \\
\text { DAP }\end{array}$ & $\begin{array}{c}60 \\
\text { DAP }\end{array}$ & $\begin{array}{c}90 \\
\text { DAP }\end{array}$ & $\begin{array}{l}120 \\
\text { DAP }\end{array}$ \\
\hline $\mathbf{T}_{1}$ & 157.88 & 414.79 & 531.81 & 31.58 & 83.01 & $\begin{array}{l}106.29 \\
(10.00)\end{array}$ & 105.15 & 335.57 & 442.14 & 15.33 & 72.46 & 99.59 \\
\hline $\mathbf{T}_{2}$ & 133.53 & 341.52 & 472.37 & 26.71 & 68.30 & $\begin{array}{l}94.47 \\
(8.90)\end{array}$ & 79.89 & 262.52 & 384.59 & 12.31 & 52.58 & 79.17 \\
\hline $\mathbf{T}_{\mathbf{3}}$ & 104.55 & 198.72 & 237.91 & 20.91 & 39.75 & & 55.58 & 123.34 & 158.02 & 9.90 & 26.44 & 37.0 \\
\hline $\mathbf{T}_{4}$ & 141.28 & 289.28 & 352.69 & 28.26 & 57.85 & $\begin{array}{l}70.54 \\
(7.47)\end{array}$ & 88.83 & 209.47 & 285.79 & 12.96 & 35.94 & 55.61 \\
\hline $\mathbf{T}_{5}$ & 100.85 & 202.60 & 311.23 & 20.17 & 40.52 & $\begin{array}{l}62.25 \\
(6.15)\end{array}$ & 58.22 & 145.82 & & 9.51 & 29.75 & 37.75 \\
\hline$T_{6}$ & 139.05 & 289.88 & 407.44 & 27.81 & 57.91 & $\begin{array}{l}81.48 \\
(8.37)\end{array}$ & 87.52 & 209.31 & 317.77 & 12.93 & 40.96 & 70.27 \\
\hline $\mathbf{T}_{7}$ & 127.29 & 181.52 & 221.27 & 25.46 & 36.36 & $\begin{array}{l}44.25 \\
(5.35)\end{array}$ & 77.11 & 103.08 & 126.04 & 11.81 & 23.49 & 28.17 \\
\hline $\mathrm{T}_{8}$ & 139.21 & 343.95 & 446.53 & 27.84 & 68.79 & $\begin{array}{l}91.13 \\
(8.91)\end{array}$ & 84.79 & 258.51 & 371.20 & 14.13 & 48.27 & 78.92 \\
\hline$T_{9}$ & 116.83 & 287.10 & 399.06 & 23.37 & 57.42 & $\begin{array}{l}77.10 \\
(8.63)\end{array}$ & 67.37 & 208.84 & 310.96 & 11.58 & 48.78 & 74.47 \\
\hline S.Em $( \pm)$ & 8.37 & 23.41 & 44.97 & 0.62 & 4.67 & 0.60 & 7.64 & 23.48 & 30.97 & 0.80 & 5.94 & 9.47 \\
\hline C.D.(0.05) & 17.74 & 49.63 & 95.33 & 1.31 & 9.90 & 1.28 & 16.20 & 49.78 & 65.66 & 1.70 & 12.59 & 20.08 \\
\hline
\end{tabular}

DAP - days after planting

Value in parenthesis are square root transformed values 
Int.J.Curr.Microbiol.App.Sci (2018) 7(5): 925-931

Table.3 Effect of intercropping on physiological parameters of taro cv. Mukhi Pan

\begin{tabular}{|c|c|c|c|c|c|c|c|c|}
\hline \multirow[t]{2}{*}{ Treatments } & \multicolumn{3}{|c|}{ Leaf area index } & \multicolumn{3}{|c|}{ Harvest index } & \multicolumn{2}{|c|}{$\begin{array}{l}\text { Net assimilation rate } \\
\left(\mathrm{g} \mathrm{m}^{-2} \text { day }^{-1}\right)\end{array}$} \\
\hline & $\begin{array}{c}60 \\
\text { DAP }\end{array}$ & $\begin{array}{c}90 \\
\text { DAP }\end{array}$ & $\begin{array}{l}120 \\
\text { DAP }\end{array}$ & $\begin{array}{c}60 \\
\text { DAP }\end{array}$ & $\begin{array}{c}90 \\
\text { DAP }\end{array}$ & $\begin{array}{c}120 \\
\text { DAP }\end{array}$ & $\begin{array}{l}\text { 60-90 } \\
\text { DAP }\end{array}$ & $\begin{array}{l}\text { 90-120 } \\
\text { DAP }\end{array}$ \\
\hline $\mathbf{T}_{1}$ & 1.35 & 1.66 & 2.47 & 66.56 & 80.94 & 83.15 & $\begin{array}{c}0.002 \\
(0.7088)\end{array}$ & $\begin{array}{c}0.00028 \\
(0.70730)\end{array}$ \\
\hline $\mathrm{T}_{2}$ & 1.29 & 1.44 & 2.25 & 59.49 & 76.58 & 81.36 & $\begin{array}{c}0.002 \\
(0.7085)\end{array}$ & $\begin{array}{c}0.00035 \\
(0.70735)\end{array}$ \\
\hline$\overline{T_{3}}$ & 0.96 & 1.06 & 2.08 & 53.18 & 61.83 & 66.35 & $\begin{array}{c}0.001 \\
(0.7079)\end{array}$ & $\begin{array}{c}0.00012 \\
(0.70719)\end{array}$ \\
\hline $\mathbf{T}_{4}$ & 1.15 & 1.31 & 2.27 & 62.74 & 72.23 & 81.49 & $\begin{array}{c}0.002 \\
(0.7084)\end{array}$ & $\begin{array}{c}0.00021 \\
(0.70725)\end{array}$ \\
\hline$\overline{T_{5}}$ & 0.91 & 1.29 & 2.12 & 57.64 & 72.05 & 60.25 & $\begin{array}{c}0.001 \\
(0.7081)\end{array}$ & $\begin{array}{c}0.00035 \\
(0.70735)\end{array}$ \\
\hline $\mathrm{T}_{6}$ & 1.16 & 1.48 & 2.28 & 62.91 & 72.01 & 77.87 & $\begin{array}{c}0.003 \\
(0.7092)\end{array}$ & $\begin{array}{c}0.00034 \\
(0.70735)\end{array}$ \\
\hline$\overline{T_{7}}$ & 0.92 & 0.99 & 2.34 & 60.34 & 56.61 & 56.65 & $\begin{array}{c}0.001 \\
(0.7078)\end{array}$ & $\begin{array}{c}0.00013 \\
(0.70720)\end{array}$ \\
\hline $\mathrm{T}_{8}$ & 1.30 & 1.45 & 2.77 & 60.93 & 75.06 & 83.08 & $\begin{array}{c}0.002 \\
(0.7084)\end{array}$ & $\begin{array}{c}0.00028 \\
(0.70730)\end{array}$ \\
\hline$\overline{T_{9}}$ & 1.24 & 1.65 & 2.11 & 57.64 & 72.63 & 77.77 & $\begin{array}{c}0.002 \\
(0.7082)\end{array}$ & $\begin{array}{c}0.00024 \\
(0.70728)\end{array}$ \\
\hline S.Em $( \pm)$ & 0.14 & 0.15 & 0.15 & 2.76 & 5.13 & 4.99 & 0.00020 & 0.000040 \\
\hline C.D.(0.05) & 0.30 & 0.32 & 0.32 & 8.26 & 10.87 & 10.58 & 0.00042 & 0.000084 \\
\hline
\end{tabular}

DAP - days after planting

Value in parenthesis are square root transformed values

Table.4 Effect of intercropping on yield attributes of Taro cv. Mukhi Pan at harvest

\begin{tabular}{|c|c|c|}
\hline Treatments & Taro yield (t/ha) & Intercrops yield (t/ha) \\
\hline $\mathbf{T}_{\mathbf{1}}-$ taro sole crop & 23.90 & - \\
\hline $\mathbf{T}_{2}-$ taro + cowpea $(1: 1)$ & 19.20 & 1.13 \\
\hline $\mathbf{T}_{\mathbf{3}}-$ taro + cowpea $(1: 2)$ & 9.50 & 1.72 \\
\hline $\mathbf{T}_{4}-$ taro + French bean $(1: 1)$ & 14.80 & 0.99 \\
\hline $\mathbf{T}_{\mathbf{5}}-$ taro + French bean $(1: 2)$ & 8.56 & 0.32 \\
\hline $\mathbf{T}_{\mathbf{6}}-$ taro + turmeric $(1: 1)$ & 15.21 & 7.57 \\
\hline $\mathbf{T}_{7}-$ taro + turmeric $(1: 2)$ & 6.21 & 17.20 \\
\hline $\mathbf{T}_{\mathbf{8}}-$ taro + ginger $(1: 1)$ & 17.15 & 15.13 \\
\hline $\mathbf{T}_{\mathbf{9}}-$ taro + ginger $(1: 2)$ & 16.08 & 30.17 \\
\hline $\mathbf{T}_{10}$-cowpea as sole crop & - & 4.83 \\
\hline $\mathbf{T}_{11}-$ French bean as sole crop & - & 1.90 \\
\hline $\mathbf{T}_{12}$-turmeric as sole crop & - & 35.16 \\
\hline $\mathbf{T}_{\mathbf{1 3}}$-ginger as sole crop & - & 43.11 \\
\hline S.Ed( $( \pm)$ & 1.20 & 4.72 \\
\hline $\mathrm{CD}(\mathbf{0 . 0 5})$ & 2.48 & 9.74 \\
\hline
\end{tabular}




\section{Yield}

Data on yield parameters at harvest were found significant differences among the treatments. Maximum corm yield (23.90 t/ha) was recorded from taro sole crop which was significantly higher than the rest of the treatments (Table 4). Among the intercropped treatments maximum yield (19.20 t/ha) was recorded in taro with single row of cowpea and minimum corm yield (6.21 t/ha) in taro with double row of turmeric. The results are in conformity with the finding of Zarate et al., (2007) that the highest yield of corms, cormels were obtained under monocrop system. Thirumdasu et al., (2015) also discussed that poor yield performance in intercropping may be due to simultaneous structural growth and corm development between component crops and thus demands simultaneous supply of assimilates to both sinks which may lead to intensive competition resulting in less synthesis of food material and poor development of corm in term of yield and yield attributes. Similar trend was also observed in corm yield per hectare by Zarate et al., (2007) and Amanullah et al., (2006).

\section{References}

Amanullah MM, Alagesan A, Vaiyapuri K, Sathyamoorthi K, Pazhanivelan S (2006). Effect of intercropping and organic manures on weed control and performances of cassava (Manihot esculenta Crantz.). J Agron 5 (4):589594.

Biradar RS, Venkateswaralu T, Hrishi N (1978). Leaf-area estimation in Colocasia. J Root Crops 4 (2): 51-53.

Chattopadhyay A, Mukhopadhyay SK, Rajib N (2008). Short Duration Vegetables as Intercrops in Elephant Foot yam in the Gangentic Alluvium of West Bengal: Analysis of Growth, Yield and Economics. J Root Crops 34(1): 10-14
Daellenbach GC, Kerridge PC, Wolfe MS, Frossard E, Finckh MR (2005). Plant productivity in cassava- based mixed cropping systems in Coluombian hillside farms. Agric Ecosyst and Environ 105: 595-614.

Evaluation of performance of rice (Oryza sativa) and taro (Colocasia esculenta) in a mixed cropping system. Ghana $\mathbf{J}$ Agric Sci 37: 49-57.

Gregory FG (1926). The effect of climate condition on growth of barley. Ann Bot. 40 (1): 1-26

Hokmalipour S, Darbandi MH (2011). Physiological growth indices in corn (Zea mays L.) cultivars as affected by nitrogen fertilizer levels. World Appl Sci J 15 (12): 1800-1805.

Kuhlase LM, Ossom EM, Rhykerd R L (2009). Effect of plant population on morphological and physiological parameters of intercropped sweetpotato (Ipomoea batatas (L.) Lam.) and Groundnur (Arachis hypogeal L.). Acad J Plant Sci 2(1):16-24.

Mabhaudhi T, Modi AT, Beletse YG (2013). Agronomic assessment of a tarobambara intercrop under rainfed conditions. Acta Hortic 597-602.

Njoku DN, Muoneke CO (2008). Effect of cowpea planting density on growth, yield and productivity of component crops in cowpea/cassava intercropping system. J Trop Agric Food and Ext 7: 106-113.

Oguzor NS (2007). Yield characteristics and growth of cassava - soybean intercropping. Agric J 2 (3): 348-350.

Oliveira FL de, Ribeiro R de. LD, Silva VV, Guerra JGM, Almeida DL de (2004). Main development in direct planting and in conjunction with sunhemp under organic management. Hortic Bras, 22(3):638-641.

Oliveira FL, Guerra JGM, Ribeiro, RLD, Almeida DL, Silva EE, Urquiaga S, 
Espindola JAA (2007). The use of sunn hemp as green manure intercropped with taro. Hortic Bras 25: 562-566.

Osundare B, Agboola AA (2003). Effect of different companion crops on the performance of cassava. Moor J Agric Res 4(1): 50-53.

Sagos R, Bam R, Adueing JM, Haleegoah J, Dedzoe D, Teiteh J P, Ankomah A, Osei JK, Kantanka OS (2004).

Thirumdasu RK, AKB Devi and Thokchom M. (2015). Analysis of growth, physiological aspects and yield of elephant foot yam, Amorphophallus campanulatus Roxb Blume cv Gajendra in spice intercropping system under sloppy foothills of Imphal East. Intl $\mathbf{J}$ Farm Sci, 5(4): 118-126.

Watson DJ (1947). Comparative physiological studies in growth of field crops. 1. Variation in net assimilation rate and leaf area between species and varieties, and within and between years. Ann Bot. 11: 41-76.

Yoshida S (1981). Fundamental of Rice Crop. International rice research institute, Los Banos, Laguna, Philippines. Pp. 61.

Zarate NAH, Vieira MdoC, Guiliani AR, Helmich M, Chiquito EG, Amadori AH. (2006). Chinese taro in monocrop system and intercropped with Brasilia carrot and Quatro estacoes lettuce. Hortic Bras 24 (3): 324-328.

Zarate NAH, Vieira MdoC, Helmich M, Chiqueto E G, Quevedo LF de, Soares EM. (2007). Yield and gross income of taro culture in monocrop system and intercropped with parsley and coriander cultures. Acta Sci Agro 29 (1): 83-89.

\section{How to cite this article:}

Momoko Thokchom, Loitongbam Sulochana Devi, Ravi Kiran Thirumdasu, A.K. Bijaya Devi and James, K.H. 2018. Growth, Physiological Studies and Yield of Taro (Colocasia esculenta Schott) cv. Mukhi Pan as Influenced by Intercropping and Row Pattern under Manipur Condition. Int.J.Curr.Microbiol.App.Sci. 7(05): 925-931. doi: https://doi.org/10.20546/ijcmas.2018.705.113 